\title{
Revista Água Viva \\ UMA SÓ PRECE? A CANÇÃO COMO GESTO SOCIAL EM PONTO DE PARTIDA
}

\section{ONE PRAYER? SONG AS SOCIAL GESTUS IN THE PLAY PONTO DE PARTIDA}

\author{
Rafael Gazzola de Lima ${ }^{1}$
}

\begin{abstract}
RESUMO: Neste trabalho, realizamos uma leitura crítica da canção Prece, composta por Gianfrancesco Guarnieri e Sérgio Ricardo, como parte do drama Ponto de partida, de Guarnieri. Considerando as especificidades da linguagem cancional, investigamos de que maneira essa canção nos ajuda a compreender não só o momento histórico que a peça retrata, como também o nosso próprio presente histórico. Nossa hipótese é a de que, por meio dessa canção, os compositores realizariam o princípio brechtiano de gesto social, revelando as leis sociais pelas quais se manifesta o comportamento dos personagens, demonstrando as relações entre o aspecto violento da sociedade brasileira e o propósito de manutenção de privilégios socioeconômicos por parte das classes mais favorecidas.
\end{abstract}

Palavras-chaves: Canção brasileira; Sérgio Ricardo; Gesto social.

ABSTRACT: This paper presents a critical analysis of the song Prayer, by Gianfrancesco Guarnieri and Sérgio Ricardo, which is part of the drama Ponto de partida, by Guarnieri. Considering the specificities of the language of the song, we investigate in which ways this song helps us to understand not only the historical moment that the play portrays but also our own historical present. Our hypothesis is that through this song the composers realize the brechtian principle of social Gestus, exposing the relations between the violent aspect of the Brazilian society and the purposes of maintaining socialeconomic privileges for favored social classes.

Keywords: Brazilian song; Sérgio Ricardo; Social Gestus.

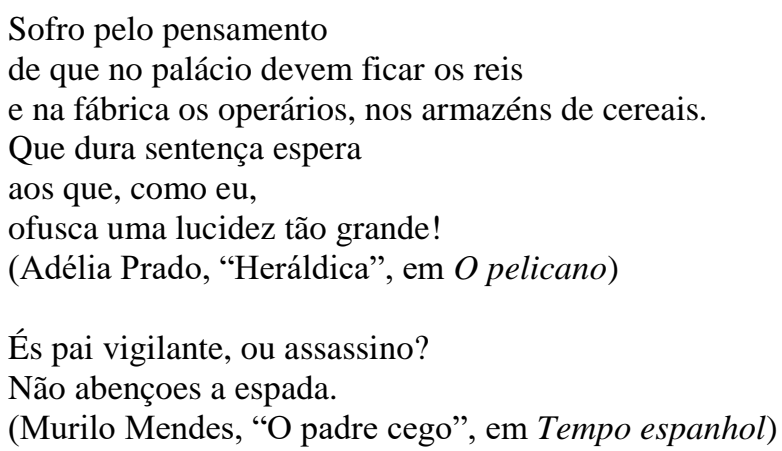

\footnotetext{
${ }^{1}$ Mestrando no Programa de Pós-Graduação em Literatura da Universidade de Brasília (PósLIT/UnB), no qual desenvolve pesquisa intitulada "Vozes abafadas: corpo, canção e catarse em Ponto de partida, de Sérgio Ricardo e Gianfrancesco Guarnieri”. E-mail: rgazzola@gmail.com.
} 


\section{INTRODUÇÃO}

São tempos sombrios esses. Sombrios os tempos em que o Estado brasileiro assassinou um jornalista de esquerda na prática hedionda da tortura. Sombrios os tempos em que uma vereadora de esquerda, mulher negra, feminista e lésbica, é executada por denunciar a violência policial e a ação das milícias no Rio de Janeiro. Era sombrio o 1975 de Vladimir Herzog, é sombrio o 2018 de Marielle Franco.

Escrito por Gianfrancesco Guarnieri em 1976, em memória de Herzog, e encenado pela primeira vez nesse mesmo ano, sob a direção de Fernando Peixoto, no Teatro TAIB, em São Paulo, o drama Ponto de partida ajuda-nos a entender os tempos difíceis que atravessamos em nosso país. Nesse quesito, têm especial função as canções da peça (quase todas com letra de Guarnieri e música de Sérgio Ricardo, à exceção da cançãotítulo, inteiramente composta por Sérgio). Neste artigo propomos uma leitura crítica de uma dessas canções, intitulada Prece, buscando compreender de que maneira os elementos formais da canção são mobilizados de forma a figurar esteticamente as contradições do momento histórico retratado pela peça. Buscamos, ainda - e talvez seja mesmo essa a questão essencial -, investigar em que medida essas contradições desveladas na canção nos ajudam a compreender o nosso presente histórico e o legado de violência como meio de manutenção das estruturas de poder econômico e político, marca persistente da experiência histórica brasileira. Para nos auxiliar na tarefa de realizar essa ponte entre momentos históricos distintos, lançamos mão da noção de gesto social conforme proposto em alguns dos ensaios teóricos de Bertolt Brecht (2005a; 2005b; 2005c) sobre o teatro.

Antes, porém, da análise crítica da canção propriamente dita, faremos uma breve exposição dos pressupostos críticos que nos guiam, seguida de um breve exame da noção de gesto social em Brecht, além de algumas notas sobre a persistência dos meios violentos de manutenção das estruturas socioeconômicas na história do Brasil.

\section{Alguns pressupostos para a crítica da canção}

Para a análise crítica que desenvolvemos aqui, partimos dos pressupostos de Antonio Candido (1967), tomando criticamente os elementos estéticos da obra de arte 
enquanto captação da dinâmica social nacional. Se, por um lado, não é impróprio centrarmos a análise crítica de uma canção em sua letra - dada a própria centralidade que esse elemento tem na linguagem cancional, em termos de seus usos sociais -, por outro lado empobrece bastante a análise ignorarmos que a fruição dessa letra se dá geralmente mediada por uma melodia, cantada por uma certa voz, cuja textura sonora é também carregada de significado. Além disso, aquela melodia, via de regra, é sustentada por um arranjo harmônico e um determinado ritmo, executados por instrumentos dotados de um certo timbre. Soma-se a tudo isso a questão da performance, conceito tomado mais ou menos livremente de empréstimo de Paul Zumthor (1997) e entendido aqui como o processo de atualização de virtualidades que cada execução de uma canção realiza face à composição. Esse conceito, no entanto, precisa ser relativizado quando se trata de um produto fonográfico, pois, se na concepção zumthoriana a ideia de performance está ligada à execução presencial e imediata da poesia oral, precisamos colocar o conceito em perspectiva para considerar as implicações da inserção do produto fonográfico no contexto da indústria cultural ${ }^{2}$.

Não se trata, no entanto, de subentender que toda boa análise crítica de uma canção deva destrinchá-la minuciosamente em sua estrutura formal. Trata-se tão-somente de afirmar que não se deve deixar de lançar mão desses recursos sempre que - e apenas quando - eles ajudem a elucidar as maneiras com que é possível à canção dizer o que diz - por meio da palavra e para além dela. Precisamos, assim, levar em consideração sempre que possível essa série de mediações se quisermos compreender o fenômeno da canção brasileira em sua complexidade. Augusto de Campos (1986) expressa isso muito bem, no poema que escreveu em homenagem a Torquato Neto, depois de sua morte, intitulado Como é, Torquato:

\footnotetext{
${ }^{2}$ Embora apontemos aqui a importância da questão da performance na análise crítica de uma canção, ela não será abordada especificamente na análise realizada neste artigo por conta de uma limitação que enfrentamos pela própria condição de produto fonográfico da canção que tomamos como objeto. Se a canção Prece foi originalmente concebida para ser cantada pelos vários personagens da peça, a gravação a que temos acesso (lançada em compacto duplo, com as demais canções da peça, pela Discos Marcus Pereira, em 1977, com Sérgio Ricardo e o Grupo Maria Déia) é inteiramente cantada apenas por um intérprete, o próprio Sérgio Ricardo, o que inviabiliza considerarmos possíveis nuances de performance entre os diversos personagens do drama. Esses limites, no entanto, podem ser compensados em parte com a leitura da peça publicada em livro (GUARNIERI, 1976), para contextualizar a relação das estrofes com cada um dos personagens que cantam, como faremos aqui.
} 
estou pensando/ no mistério das letras de música/ tão frágeis quando escritas/ tão fortes quando cantadas/ [...] a palavra cantada/ não é a palavra falada/ nem a palavra escrita/ a altura a intensidade a duração a posição/ da palavra no espaço musical/ a voz e o mood mudam tudo/ a palavra-canto/ é outra coisa (p. 309).

Há algo, pois, que determina a eficácia e o encanto da canção, para usar termos caros a Tatit (1986), e que está para além da letra, ainda que dependendo dela.

\section{Gesto e sociedade, ou ordem contra justiça}

Em linhas gerais, o enredo do drama de Guarnieri se desenvolve em torno de uma investigação acerca da morte do personagem Birdo, cujo corpo pendido de uma árvore abre a cena. Toda a história é situada em tempo e espaço remotos (aparentemente uma vila medieval) e se constitui ao redor de cinco personagens: o casal D. Félix e Áida, senhores da aldeia, além de três personagens próximos ao morto - Ainon, seu pai; Maíra, seu par amoroso; Dôdo, seu amigo. Prece é a última canção a ser apresentada na peça, em um momento do enredo em que D. Félix começa a perceber um certo comportamento suspeito de sua esposa, Áida, diante do inquérito instaurado para investigar a morte de Birdo. Nesse ponto do drama, ao se perceber em algum apuro pelo andamento do inquérito, Áida insta seu marido a encerrar as investigações.

Composta por cinco estrofes ${ }^{3}$, sem refrão, cada uma delas cantada por cada um dos cinco personagens da peça, a camada textual de Prece pode ser dividida - grosso modo - em dois grandes blocos. De um lado, as duas primeiras estrofes, cantadas por D. Félix e Áida. A prece dos senhores da aldeia é pelo restabelecimento da ordem, em suma, pelo fim do inquérito. Do outro lado, as três estrofes restantes, cantadas pelos personagens próximos ao morto: Ainon, Maíra e Dôdo. A oração destes é de desespero e dor, um clamor sobretudo por justiça.

Analisaremos, neste artigo, a canção a partir desse prisma da oposição entre ordem e justiça. Apesar de esses dois termos não constituírem claramente um par de opostos,

\footnotetext{
${ }^{3}$ Na peça publicada em livro (GUARNIERI, 1976), há ainda uma sexta estrofe, composta inteiramente de fragmentos das três anteriores. A rubrica indica que ela é cantada em coro por Ainon, Maíra e Dôdo. Essa estrofe, no entanto, está ausente da gravação de Sérgio Ricardo, razão pela qual não a consideraremos aqui.
} 
pensamos aqui na noção brasileira "muito própria" de ordem de que fala Tales Ab'Saber (2015):

Essa noção, vaga, mas ativa; indefinida, mas muito afirmativa, é usada em momentos estratégicos por homens de Estado e está presente no horizonte do discurso conservador nacional e na sustentação das ações policiais mais duras, em geral de impacto social muito violento (não paginado, grifos no original).

Segundo o autor, essa noção de ordem, que guia grande parte da ação política conservadora no país, aparentemente se desconecta de qualquer processo histórico concreto, parecendo pairar abstratamente sobre a vida política nacional. Constituindo um "desejo social fantasmático", o anseio social pela ordem tem como principal agente as forças policiais, que têm agido na história do país de forma notoriamente violenta. Essa ideia aparentemente abstrata de ordem

[...] pode até mesmo se colocar em clara oposição à ideia moderna de lei - entendida como alguma norma racional pactuada política e socialmente por um povo e uma nação e também, em nível mais amplo, entre as nações. É possível e provável, e os exemplos são inúmeros, que no Brasil tenha se constituído um verdadeiro campo político, e psíquico, de uma ação pela ordem que não corresponda aos direitos universais, relativos à história do processo normativo e político ocidental, os mesmos que, para estar inserido, o país também professa; e, até mesmo, em um grau ainda mais fantástico, é possível que tal chamado à ordem não corresponda ao próprio campo e à estrutura das leis, mais ou menos racionais, mais ou menos sociais, vigentes no país (AB'SABER, 2015, não paginado).

É justamente nesse sentido apontado por Ab'Saber que entendemos as noções de ordem e de justiça como forças que se tensionam na história do Brasil. A rigor, temos um sistema judicial muitas vezes mais empenhado na manutenção das estruturas políticas e econômicas (a manutenção da ordem) que propriamente na garantia dos direitos (a justiça). No limite, essa tendência redunda na manutenção dos privilégios daqueles que já os têm e, simultaneamente, na negação desses mesmos privilégios àqueles que foram alijados historicamente. Ainda segundo o autor, esse anseio conservador pela ordem tem legitimado na história brasileira diversas medidas de exceção, "a começar pelo direito à 
tortura e ao assassinato". Mais uma vez não podemos deixar de invocar os casos emblemáticos de Herzog e Marielle. Voltaremos a isso mais à frente.

Levando ainda em consideração que, na canção Prece, essa oposição entre ordem e justiça é tratada em linguagem eclesiástica, podemos pensar na hipótese de um possível reflexo da relação ambígua da igreja católica com o regime militar: os dois polos de referência, nesse sentido, seriam, de um lado, as "Marchas da Família com Deus pela Liberdade", e, de outro, as Comunidades Eclesiais de Base e a Teologia da Libertação ${ }^{4}$. Mais à frente, voltaremos também a tratar dessa questão, analisando - à luz do momento histórico em que se insere o drama de Guarnieri e o qual ele busca retratar - de que maneira essas contradições se internalizam na tessitura da canção objeto deste artigo.

Em nossa análise, atentaremos, porém, para as diferenças discursivas no interior desses dois grupos maiores, de forma a desvelar os tipos sociais representados por cada personagem, conforme a concepção de gesto social proposta por Bertolt Brecht entendida como um elemento estilístico que revela comportamentos típicos, leis sociais e condições econômico-políticas sob as quais se manifestam os comportamentos de cada personagem (BRECHT, 2005a).

Antes de realizarmos a análise crítica da canção, é importante pontuar algumas questões em torno desse conceito brechtiano. Partimos, para isso, da sugestão de Walter Benjamin (1987), a respeito da função primordial da canção no teatro épico de Brecht, no sentido de que ela promove a interrupção do fluxo dramático, permitindo revelar, pelo gesto, o que há de ambíguo ou pouco transparente nas palavras e ações dos personagens.

Apesar de Brecht aparentemente não definir de forma clara o conceito de gesto social (consequência até do caráter mais prático de seus textos sobre teatro, que em geral não constituem uma teoria sistemática ${ }^{5}$ ), ele é central para o pensamento brechtiano sobre a função social do teatro. Citemos alguns dos textos em que o autor parece se aproximar

\footnotetext{
${ }^{4}$ A respeito das contradições do envolvimento da igreja católica com questões políticas, econômicas e sociais durante a ditadura, cf. o bastante esclarecedor capítulo "Igreja Católica: 1945-1970" de FAUSTO, Boris; PIERUCCI, Antônio Flávio de Oliveira et al. História geral da civilização brasileira. Rio de Janeiro: Bertrand Brasil, 2007, t. 3, v. 11, p. 422-467. Cf. também o capítulo 18 de SCHWARCZ; STARLING (2015, p. 467-497).

5 "Criada na prática, atendendo, a cada momento, aos seus novos rumos, as suas teorias estéticas não formam um sistema. Seus escritos sobre o teatro são artigos e ensaios curtos que foram sendo escritos através dos anos, a maioria deles atendendo a necessidades circunstanciais. [...] Segundo se conta, ele alimentava o projeto de escrever um amplo ensaio em que deveria sistematizar todas as investigações de natureza teórica que realizou. Nunca o fez." (MACIEL, 1967, p. 6).
} 
de uma definição do termo, para que possamos daí esboçar uma possível definição mais sintética:

Chamamos esfera do gesto aquela a que pertencem as atitudes que as personagens assumem em relação umas às outras. A posição do corpo, a entoação e a expressão fisionômica são determinadas por um gesto social; as personagens injuriam-se mutuamente, cumprimentam-se, instruem-se mutuamente etc. Às atitudes tomadas de homem para homem pertencem, mesmo, as que, na aparência, são absolutamente privadas, tal como a exteriorização da dor física, na doença, ou a exteriorização religiosa. A exteriorização do 'gesto' é, na maior parte das vezes, verdadeiramente complexa e contraditória, de modo que não é possível transmiti-la numa única palavra; o ator, nesse caso, ao efetuar uma representação necessariamente reforçada, terá de fazê-lo cuidadosamente, de forma a nada perder e a reforçar, pelo contrário, todo o complexo expressivo. (BRECHT, 2005c, p. 155, grifos no original).

O gesto social é o gesto que é significativo para a sociedade, que permite tirar conclusões que se apliquem às condições dessa sociedade. (BRECHT, 2005b, p. 238).

Por fim, em um texto em que defende a "importância especial" do gesto social, "[g]esto que tenha, evidentemente, significado social, e não um gesto apenas ilustrativo e expressivo" (BRECHT, 2005a, p. 228), o dramaturgo defende os seguintes princípios político-pedagógicos para o seu teatro épico:

O teatro épico interessa-se pelo comportamento dos homens uns para com os outros, sobretudo quando é um comportamento (típico) de significação histórico-social. Dá relevo a todas as cenas em que os homens se comportam de tal forma que as leis sociais a que estão sujeitos surjam em toda a sua evidência. [...] O comportamento humano é apresentado, no teatro épico, como sendo suscetível de transformação e, o homem, como dependente de determinadas condições econômicopolíticas, condições que é, simultaneamente, capaz de modificar. [...] Em suma, é conferida ao espectador oportunidade para uma crítica do comportamento humano segundo uma perspectiva social e a cena é representada como uma cena histórica. $\mathrm{O}$ espectador passará a ter possibilidade de estabelecer comparações, no domínio do comportamento humano. (BRECHT, 2005a, p. 228).

Pelo que se depreende dos textos citados, portanto, o gesto social diz respeito a certos elementos de interpretação e de concepção cênica que tornariam patentes para o 
espectador alguns dos condicionamentos sociais que determinariam as atitudes dos personagens. O gesto social não se confunde com a performance gestual, corporal dos atores, apesar de passar também por aí: "não é somente gesto: é muito mais. Postura, atitude, tudo: é o significado traduzido em termos cênicos." (PEIXOTO, 1981, p. 70, grifo nosso). Assim, podemos considerar gesto social todo elemento expressivo que, na cena dramática, contribui para revelar as determinações sociais do comportamento dos personagens. Como dissemos anteriormente, faremos adiante uma leitura dos elementos expressivos da canção Prece, para compreender de que forma eles nos ajudam a compreender essas determinações.

Ao trabalharmos com a hipótese de que essa canção revelaria os tipos sociais dos personagens do drama de Guarnieri, estamos plenamente conscientes de que o teatro deste dramaturgo não é de forma alguma um teatro de matriz brechtiana (GUARNIERI, 1989; COSTA, 1996); nos parece, no entanto, que, por meio da música - e em especial dessa canção que analisamos -, se realizam - seja de forma consciente ou inconsciente - alguns dos pressupostos brechtianos referentes ao gesto social.

\section{Violência e manutenção da ordem no Brasil}

Antes, ainda, de passarmos à análise crítica da canção, importa registrar algumas notas sobre a função social da violência. Partindo daquela noção de ordem de que fala Ab'Saber (2015) e considerando a recorrência histórica da violência como instrumento de manutenção dessa ordem no Brasil, lancemos um breve olhar sobre a história da violência no país. Para Schwarcz e Starling (2015), a violência é um traço persistente da experiência histórica brasileira:

Certa lógica e certa linguagem da violência trazem consigo uma determinação cultural profunda. Como se fosse um verdadeiro nó nacional, a violência está encravada na mais remota história do Brasil, país cuja vida social foi marcada pela escravidão. Fruto da nossa herança escravocrata, a trama dessa violência é comum a toda a sociedade, se espalhou pelo território nacional e foi assim naturalizada. Se a escravidão ficou no passado, sua história continua a se escrever no presente. A experiência de violência e dor se repõe, resiste e se dispersa na trajetória do Brasil moderno, estilhaçada em milhares de 
modalidades de manifestação (SCHWARCZ; STARLING, 2015, p. 14).

Se as autoras localizam na experiência escravocrata pelo menos parte da origem do legado violento da sociedade brasileira, elas apontam, ao longo do livro, manifestações diversas desse legado, em geral diretamente ligadas ao propósito de manutenção da ordem política e econômica. A respeito do período que nos é caro na análise que aqui propomos, a ditadura pós-1964, as autoras ressaltam a participação de civis como condição essencial para o funcionamento da burocracia da violência durante o regime militar, deixando patente os interesses econômicos que lhe serviam de base:

Para a tortura funcionar, é preciso que existam juízes que reconheçam como legais e verossímeis processos absurdos, confissões renegadas, laudos periciais mentirosos. Também é preciso encontrar, em hospitais, gente disposta a fraudar autópsias e autos de corpo de delito e a receber presos marcados pela violência física. É preciso, ainda, descobrir empresários prontos a fornecer dotações extraorçamentárias para que a máquina de repressão política funcione com maior eficácia. No Brasil, a prática da tortura política não foi fruto das ações incidentais de personalidades desequilibradas, e nessa constatação residem o escândalo e a dor. Era uma máquina de matar concebida para obedecer a uma lógica de combate: acabar com o inimigo antes que ele adquirisse capacidade de luta. (SCHWARCZ; STARLING, 2015, p. 460-461).

Mesmo que superado, por ora, o regime militar e conquistados alguns dos princípios democráticos que, bem ou mal, ainda gozamos em nosso país, persiste, porém, o recurso à violência como principal instrumento de manutenção de privilégios. Mudouse a forma, mudaram-se as estratégias, mas, retomando os casos emblemáticos que abrem o nosso texto, é mais ou menos seguro dizer que se assemelham os motivos pelos quais foram mortos Herzog e Marielle. Ainda que não se tenha esclarecido até hoje este último caso, há fortes indícios da participação de indivíduos ligados às forças policiais no assassinato da vereadora. Novamente Schwarcz e Starling (2015) ajudam-nos a entender a continuidade entre o aparato estatal da tortura durante o regime militar e a violência policial de nossos dias:

[S]e a tortura, desde os anos 1980, não é mais uma política de Estado, ela continua disseminada nas práticas privadas ou mesmo acobertada 
nas delegacias e nas investidas policiais em bairros da periferia, onde a escala de violência e de humilhação é ainda maior e, sobretudo, contra jovens negros. Diante dessas situações, fica exposta a cidadania precarizada de certos grupos sociais, e as práticas de segregação a que continuam sujeitos. É nesses momentos que a regra democrática permanece suspensa. Até parece que o passado escravocrata mais distante e o autoritarismo nem tão longínquo deixaram uma marca incontornável do arbítrio e do ajuste de contas privados, ou delegados ao outro que incorpora a autoridade. O pior é que a prática atravessa diferentes classes sociais, não sendo monopólio de um grupo ou estrato. (SCHWARCZ; STARLING, 2015, p. 507).

Sem querer forçar uma relação esquemática entre períodos históricos tão distintos - o regime escravocrata, a ditadura pós-1964, a violência policial de nossos dias -, é claro, no entanto, que há certa continuidade nesse histórico de violência. Voltando à correlação estabelecida por Ab'Saber (2015), se o anseio conservador pela manutenção da ordem ensejou, em diversos momentos da história do país, o recurso a regimes de exceção, esse mesmo anseio tem legitimado hoje a ação violenta de indivíduos ligados às forças policiais, certos da impunidade.

Feitas essas não tão breves observações preliminares, passemos enfim à análise da canção objeto deste artigo, buscando compreender o quanto ela nos ajuda a elucidar essas questões e a compreender o nosso presente à luz da experiência histórica brasileira.

\section{De partida}

Um aspecto marcante da canção Prece é a recorrência de motivos textuais entre uma estrofe e outra. Cada uma das estrofes se inicia com o personagem repetindo textualmente o último verso da estrofe anterior, de outro personagem. Essa característica, se remete em parte às ladainhas e responsórios do catolicismo, remete ainda mais aos desafios de viola dos cantadores - aspecto reforçado por diversos outros elementos da canção, como as escalas melódicas nos modos dórico e mixolídio, bastante recorrentes na música nordestina, o ritmo tendente ao baião dos dois últimos versos de cada estrofe, além da regularidade métrica dos versos de sete sílabas, em redondilha maior. Todos esses elementos, por um lado, remetem à cultura popular, cuja recuperação é tão cara às tenções comunicativas, pedagógicas, da canção de protesto, momento estético-histórico essencial 
da formação do sistema cancional brasileiro, do qual Sérgio Ricardo é um importante nome. Por outro lado, como retomaremos mais à frente, esses elementos são tensionados por elementos expressivos outros, que não se ligam diretamente à cultura popular, instaurando na canção uma sonoridade estranha, incômoda, em especial no que se refere à sequência harmônica. Não será possível aqui nos estendermos sobre essas questões, mas façamos aqui essa breve anotação, a ser revisitada em outro momento de nossa pesquisa.

Embora haja a repetição textual do desafio a que acabamos de aludir, é importante notar que a posição desses trechos em cada estrofe (no começo ou no fim) e a forma como cada um deles se apresenta no desenho melódico e harmônico da canção - assim como o fato de serem cantados por diferentes personagens da trama - alteram-lhes bastante o sentido. Além disso, não há na canção diferenças significativas no arranjo instrumental de uma estrofe para a outra; essa constância na trama sonora da canção contribui para que concentremos a atenção nos deslocamentos de sentido na relação entre letra e melodia de uma estrofe para outra. Essas características de recorrência fazem dessa canção, portanto, um caso bastante elucidativo da interdependência entre letra e melodia na construção de sentido da linguagem cancional. Como demonstraremos a seguir, tanto um mesmo texto pode adquirir significados distintos a depender da linha melódica e harmônica a que se associa, quanto um mesmo desenho melódico pode desempenhar funções discursivas distintas a depender do texto cantado.

Mesmo acreditando sempre que só é possível apreender plenamente o sentido de uma canção escutando-a - sendo a mera leitura de sua letra experiência desfibrada desse processo -, vale a pena reproduzir aqui a porção textual da canção, para melhor visualização de algumas das questões que abordamos em nossa análise. Recomendamos, no entanto, que o leitor procure escutá-la, para maior riqueza de leitura.

Prece

(Sérgio Ricardo / Gianfrancesco Guarnieri) 


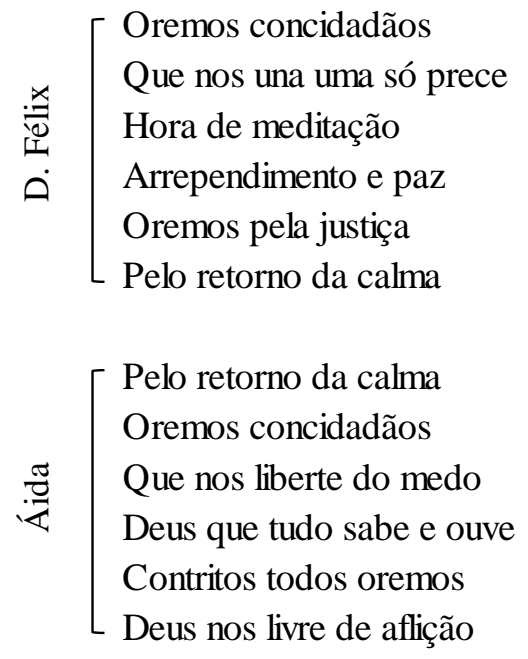

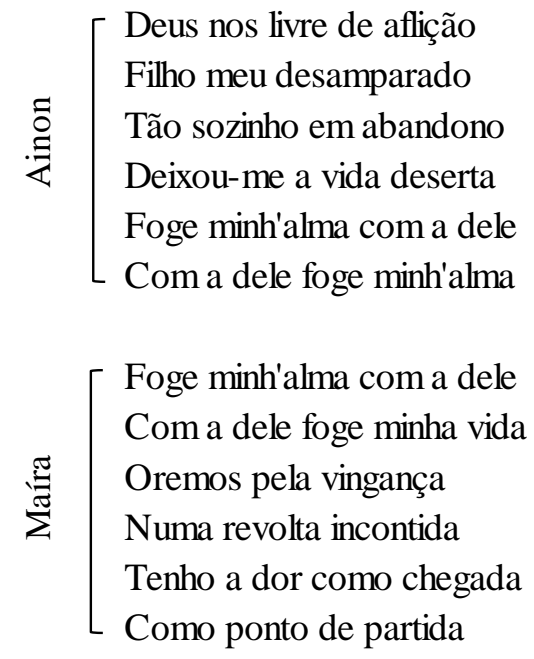

$\stackrel{\circ}{\stackrel{0}{0}}\left[\begin{array}{l}\text { Como ponto de partida } \\ \text { Tento só sobreviver } \\ \text { Tanto mal vejo ao meu lado } \\ \text { Tanto bem para querer } \\ \text { Sozinho que nem um morto } \\ \text { Eu só minto de viver }\end{array}\right.$

Mais que uma prece propriamente dita, dirigida a alguma divindade, o que está expresso textualmente na canção é uma convocação à prece, ou antes uma ordem, dirigida de cima para baixo ao corpo social composto pelos personagens da trama. D. Félix inicia a canção convocando toda a aldeia a uma oração em uníssono: textualmente, "que nos una uma só prece". O próprio desenho melódico desse trecho, em direção às notas agudas, materializa esse tom de chamado, de conclamação em alta voz. Todo o povo é, assim, conclamado a ficar quieto, pois é "hora de meditação, arrependimento e paz"; a oração de todos deve ser "pelo retorno da calma". Nesses dois últimos trechos, o desenho melódico se dirige acentuadamente ao grave, tendendo ao repouso almejado pelo personagem, interessado na manutenção da ordem social. No entanto, esse desejo de ordem é o tempo todo tensionado pelo arranjo instrumental. A percussão bastante marcada da canção; incursões pontuais de queixada e prato na parte instrumental anterior ao canto; os ataques fortes e repetidos de tambor ao longo de toda a estrofe; o uso percussivo de um instrumento de corda (possivelmente um cavaquinho ou instrumento semelhante) ao longo dos quatro primeiros versos; o uso também percussivo do piano, em rápida sequência cromática descendente, que marca a passagem do quarto para o quinto verso; e, por fim, o ritmo de baião dos dois últimos versos, com marcação de 
tambor e triângulo: todos esses elementos contribuem para manter uma permanente tensão, ao longo de toda a canção.

Se no fim da primeira estrofe, o personagem de D. Félix entoa o trecho "pelo retorno da calma" em direção ao grave, sem grandes alongamentos vocálicos, tendendo portanto ao repouso, em tom de conclusão, a personagem de Áida abre a estrofe seguinte retomando essa mesma frase, porém com aquele desenho melódico inicial em direção ao agudo, desenho esse que, conforme Tatit (2002), tende a conotar a sensação de tensão e sofrimento, devido ao maior esforço vocálico necessário à emissão e manutenção de notas agudas. Se em D. Félix o agudo de "uma só prece" era de conclamação, aqui o agudo de "pelo retorno da calma" expressa a tensão de Áida em relação aos rumos do inquérito, uma vez que há nesse momento da trama indícios bastante claros de que seja ela a responsável pela morte de Birdo.

Em termos harmônicos, a sequência de acordes reforça também - como já dissemos a respeito dos aspectos rítmicos - a tensão explícita no texto entre a manutenção da ordem e o clamor por justiça. Quase não há repouso na progressão harmônica da canção. Os poucos momentos que tendem ao repouso são muito breves, carregados de ambiguidade e logo abalados por um outro elemento da trama sonora. Nessa segunda estrofe, cantada por Áida, por exemplo, o quarto verso menciona um "Deus que tudo sabe e ouve". A melodia tendendo ao grave, combinada com a progressão harmônica que desliza entre os três primeiros graus de uma tonalidade algo dúbia (entre as escalas próximas de mi bemol dórico e ré bemol maior), dá a esse trecho uma sonoridade de certa ameaça - uma gravidade tensionada, digamos. O trecho é ainda abalado por aquela sequência cromática executada pelo piano a que já aludimos e que introduz o ritmo mais intenso do baião dos quinto e sexto versos, os quais se inscrevem em um arco melódico mais amplo, conotando, assim, a ideia de movimento. A estrofe termina com o texto "Deus nos livre de aflição" em direção ao grave, com o tom de quem deseja se desembaraçar de um problema. Mais que o desejo pela manutenção da ordem social expresso por D. Félix, o tom aqui é de anseio por livramento pessoal, de alguém que se sabe culpada mas que quer logo se safar do problema - mesmo sabendo certa sua impunidade, sendo seu marido o responsável pelo inquérito, a personagem quer se livrar o mais breve possível do incômodo. 
A terceira estrofe, cantada por Ainon, pai de Birdo, começa, por sua vez, com o mesmo texto ("Deus nos livre de aflição") em direção ao agudo. Mais uma vez, o sentido textual é alterado pela melodia. Se o trecho, quando cantado por Áida, significava a antecipação do alívio, na boca de Ainon é expressão do desespero de quem perdeu seu filho. O desespero impotente do personagem, retratado nessa estrofe, é reforçado pela camada textual, em expressões como "desamparado", "sozinho em abandono", "vida deserta". Assim, na interação entre letra e melodia, figura-se o amálgama, traço marcante desse personagem, entre desespero (nos trechos tendentes ao agudo) e impotência (nos trechos direcionados ao grave). Como na estrofe anterior, a passagem do quarto para o quinto verso é marcada pela ambiguidade: do total desolamento e imobilidade dos versos "tão sozinho em abandono / deixou-me a vida deserta" (inscritos em uma melodia em que há pouca variação, e uma tendência quase que exclusivamente direcionada ao grave) a um indício de movimento (ainda que sem rumo) em "foge minh'alma com a dele / com a dele foge minh'alma" (movimento ressaltado, como dissemos anteriormente, pela sequência cromática executada ao piano, pelo ritmo marcado do baião e pela melodia que, alternadamente, ora ascende, ora descende). O movimento do trecho prepara a estrofe mais contundente que virá em seguida.

Diferentemente das demais, a quarta estrofe, cantada por Maíra, companheira de Birdo, retoma não apenas o último, mas os dois últimos versos da estrofe anterior, na mesma ordem, com uma ligeira alteração, trocando-se a última palavra ("alma” em Ainon, "vida" em Maíra). E se em Ainon a alma que foge com a do morto tende - em face do desenho melódico rumo ao grave - à imobilidade - ou, no limite, a uma mobilidade estéril, sem rumo -, na estrofe cantada por Maíra essa fuga é ascendente, tendendo, portanto à ação. Em contraposição à oração dos senhores da aldeia, que era pelo "retorno da calma", pelo fím da aflição, a oração de Maíra é "pela vingança". O texto dos dois últimos versos reforça a dubiedade do desenho melódico. Se, por um lado, a melodia do trecho "tenho a dor como chegada / como ponto de partida" tende em geral à

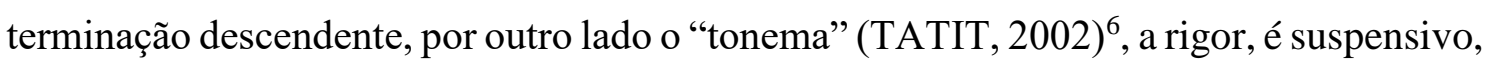
uma vez que as duas últimas sílabas sustentam a mesma nota. Assim, a passagem está

\footnotetext{
6 "Os tonemas são inflexões que finalizam as frases entoativas, definindo o ponto nevrálgico de sua significação. Com apenas três possibilidades físicas de realização (descendência, ascendência ou suspensão), os tonemas oferecem um modelo geral e econômico para a análise figurativa da melodia, a partir das oscilações tensivas da voz" (TATIT, 2002, p. 21-22).
} 
carregada, ao mesmo tempo, do tom asseverativo, conclusivo, do grave, e da continuidade do desenho melódico contínuo, suspenso. Tudo isso explicitado pelo texto: a gravidade da dor tomada como ponto do qual se parte para a ação. O trecho é ainda citação da canção tema do drama, instância de "re-corporificação" de Birdo, personagem de resto ausente da peça, pois já morto de início. O sentido de ação, de movimento, é, mais uma vez, reforçado pelo baião.

Por fim, na última estrofe, Dôdo expressa a resignação de alguém que, tendo presenciado tanta violência, voltou o foco para sua própria sobrevivência. Se a dor de Maíra é ponto de partida para seu desejo de vingança e de justiça, para Dôdo o horror que presenciou é ponto de partida para seu mero desejo de sobrevivência.

Compreendendo o gesto social de Brecht menos como uma metodologia específica de criação artística e mais como um princípio estético abrangente ${ }^{7}$, retomamos a nossa hipótese de que nessa canção Guarnieri e Sérgio revelariam, por meio da linguagem propriamente cancional, as motivações sociais subjacentes aos comportamentos individuais dos personagens do drama. Conforme Gatti (2008), Brecht almejava em seu teatro épico, "ensinar ao público que o homem não é uma essência fixa e imutável, mas um ser histórico que exerce uma função social correspondente à sua inscrição histórica" (p. 57).

É precisamente isso que Guarnieri e Sérgio revelam nessa canção, em relação com o enredo do drama: ao por a nu as motivações dos personagens no que concerne ao seu comportamento diante do inquérito, revelando - por meio da linguagem cancional, como demonstrado - seu condicionamento histórico e social, os artistas deixam clara a ligação entre a violência e os propósitos de manutenção dos privilégios sócio-econômicos das classes mais abastadas. Se essa obra ajuda a esclarecer os motivos políticos e econômicos da violência de Estado do regime militar, ajuda-nos ainda mais a compreender o momento histórico que vivemos atualmente, em que o tratamento dispensado a manifestantes pelas autoridades policiais, por exemplo, se altera radicalmente conforme o espectro

\footnotetext{
${ }^{7}$ A esse respeito, ver as seguintes afirmações de estudiosos brasileiros do pensamento brechtiano: "Brecht não fornece receitas nem leis ou dogmas sagrados [...] Brecht não é um modelo intemporal e rígido, acabado e definitivo" (PEIXOTO, 1981, p. 20). "Não se trata de instituir em nossos espetáculos e em nossos ensaios de peças os métodos brechtianos. No próprio Berliner Ensemble, os ensaios não se transformam em digressões intermináveis sobre distanciamento, empatia, Gestus, etc. Para os homens de teatro, particularmente, as teorias de Brecht são um desafio para que encontrem suas próprias soluções e descubram, sozinhos, onde afinal meteram o nariz" (MACIEL, 1967, p. 17).
} 
ideológico: aos manifestantes que ostentam a insígnia da $\mathrm{CBF}$, abraços e selfies; aos jovens universitários que protestam contra o sucateamento do ensino público, cassetetes, balas e bombas. Ainda mais uma vez cumpre trazer à lembrança as mortes de Herzog e de Marielle, à luz das quais a canção Prece ajuda-nos a compreender o quanto a violência se imiscui de interesses políticos e econômicos.

Em tempos ciosos de restauração e manutenção de privilégios, nos quais se tem invocado o nome de Deus pelas razões mais espúrias, em que se tem mobilizado o aparato judicial para a perpetuação da injustiça social, em que se têm calado à força aqueles que clamam por justiça, enquanto se brame pelo justiçamento de pequenos contraventores, é necessário reatentarmos para a potência transformadora da arte. E também da crença desde que não submetida ao jugo de interesses particulares questionáveis, mas em serviço do outro, da coletividade, pela busca da verdadeira justiça. Nesse sentido, Prece tem muito a nos dizer.

\section{REFERÊNCIAS}

AB'SABER, Tales. Ordem e violência no Brasil. In: KUCINSKI, Bernardo et al. Bala perdida: a violência policial no Brasil e os desafios para sua superação. São Paulo: Boitempo, 2015. Livro digital não paginado.

BENJAMIN, Walter. Que é o teatro épico?: um estudo sobre Brecht [1931]. . Magia e técnica, arte e política: ensaios sobre literatura e história da cultura. Trad. Sergio Paulo Rouanet. São Paulo: Brasiliense, 1987, p. 78-90.

BRECHT, Bertolt. Acerca da contribuição da música para um teatro épico. Estudos sobre teatro. Tradução de Fiama Pais Brandão. Rio de Janeiro: Nova Fronteira, 2005a, p. 225-235.

. Acerca da música-gesto [c. 1938]. . Estudos sobre teatro. Tradução de Fiama

Pais Brandão. Rio de Janeiro: Nova Fronteira, 2005b, p. 237-240.

Pequeno órganon para o teatro [1948]. Estudos sobre teatro. Tradução de

Fiama Pais Brandão. Rio de Janeiro: Nova Fronteira, 2005c, p. 125-166.

CAMPOS, Augusto de. Como é Torquato. . Balanço da bossa e outras bossas. São

Paulo: Perspectiva, 1986, p. 307-310. 
CANDIDO, Antonio. Crítica e sociologia (tentativa de esclarecimento). Literatura e sociedade: estudos de teoria e história literária. São Paulo: Companhia Editora Nacional, 1967, p. 1-17.

COSTA, Iná Camargo. A hora do teatro épico no Brasil. Rio de Janeiro: Paz e Terra, 1996.

GATTI, Luciano. Benjamin e Brecht: a pedagogia do gesto. Cadernos de filosofia alemã. São Paulo: Departamento de Filosofia da Faculdade de Filosofia, Letras e Ciências Humanas da USP, n. 12, p. 51-78, jul./dez. 2008.

GUARNIERI, Gianfrancesco. Ponto de partida: fábula em um ato, com música de Sérgio Ricardo. São Paulo: Brasiliense, 1976.

. Entrevista com Gianfrancesco Guarnieri. PEIXOTO, Fernando. Teatro em movimento. São Paulo: Hucitec, 1989, p. 44-60.

MACIEL, Luiz Carlos. Introdução. BRECHT, Bertolt. Teatro dialético: ensaios. Rio de Janeiro: Civilização Brasileira, 1967, p. 1-17.

PEIXOTO, Fernando. Brecht: uma introdução ao teatro dialético. Rio de Janeiro: Paz e Terra, 1981.

SCHWARCZ, Lilia Moritz; STARLING, Heloisa Murgel. Brasil: uma biografia. São Paulo: Companhia das Letras, 2015.

TATIT, Luiz. A canção: eficácia e encanto. São Paulo: Atual, 1986. O cancionista: composição de canções no Brasil. São Paulo: Edusp, 2002.

ZUMTHOR, Paul. Introdução à poesia oral. Tradução de Jerusa Pires Ferreira, Maria Lúcia Diniz Pochat e Maria Inês de Almeida. São Paulo: Hucitec, 1997.

Recebido em: 14 abr. 2018

Aceito em: 22 jun. 2018 